Archived version from NCDOCKS Institutional Repository http://libres.uncg.edu/ir/asu/

\title{
Appalachľan
}

B O O N E, NORTH CAROLIN A

\section{Effect Of Freshets On The Flux Of Groundwater Nitrate Through Streambed Sediments}

\author{
By: Gu, Chuanhui ${ }^{\star}$ Hornberger, G. M. ${ }^{\star}$ Herman, J. S. * Mills, A. L. *
}

\begin{abstract}
The passage of a flood wave over sandy stream sediments can cause changes in the discharge of groundwater to the stream that range from a transient reduction in the discharge rate to a reversal of flow and temporary storage of stream water in the stream sediments. These phenomena were examined in laboratory studies with an intact core and by numerical modeling to assess the effect of both physical and biological processes on the nitrate flux from nitrate-contaminated groundwater to a stream. The balance between the rates of groundwater flow through organic-rich sediments and of denitrification ultimately determines the efflux of nitrate to the stream. The transient impact on nitrate loading suggested by results from the numerical model indicates that high flood stage and lowsediment hydraulic diffusivity can result in excess nitrate loading to surface water following storm events, whereas large-sediment hydraulic diffusivity, regardless of the size of stream stage changes, facilitates greater removal of $\mathrm{NO}^{-}$by denitrification by allowing for a longer residence time of water in the subsurface.
\end{abstract}

Gu, Chuanhui, Hornberger, G. M., Herman, J. S., Mills, A. L. (2008). “Effect Of Freshets On The Flux Of Groundwater Nitrate Through Streambed Sediments." Version of record available from Water Resources. Res., 44, W05415, [DOI: 10.1029/2007WR006488],[ISSN: 0097-8078]. 


\section{Effect of freshets on the flux of groundwater nitrate through streambed sediments}

\section{Introduction}

[2] The surface of streambed sediments, i.e., the groundwater/surface water interface (GSI), is the locus of efflux of water and chemical constituents from groundwater to the stream. The streambed sediments immediately underlying the GSI are host to significant biogeochemical activity, often acting to control fluxes of solutes such as nitrate from terrestrial to aquatic ecosystems [Dahm et al., 1998; Duff and Triska, 1990; Hedin et al., 1998]. Because of the presence of labile organic matter, anoxia is common in streambed sediments where rates of microbial metabolism are high and pore water is isolated from exchange with overlying oxygenated surface water. Respiration in these environments frequently uses alternate inorganic terminal electron acceptors, such as nitrate, after oxygen is depleted. For example, low-relief coastal stream sediments can, in some portions, display high rates of denitrification as discharging, nitrate-rich groundwater passes through organicmatter-rich sediments. The combination of slow supply of electron acceptors and high rates of metabolism may result in a sharp redox gradient within a few centimeters of the sediment-water interface, thus localizing processes such as denitrification very close to the streambed surface [Hedin et al., 1998].

[3] Because biogeochemically active zones in streambed sediments can be very shallow and thin, transient hydrological events that cause rapid, short-term changes in stream stage, such as freshets (namely, a flood resulting from heavy rain or a spring thaw), might have significant effects on nutrient fluxes across the GSI. Short-term reversals of redox conditions within streambed sediments resulting from groundwater/surface water exchange may affect the nature and rates of microbial processes and the resulting chemical character of natural waters [Dahm et al., 1998]. The impact of freshets on nutrient loading to streams from groundwater, however, is largely unknown [Cirmo and McDonnell, 1997].

[4] When a flood wave passes down a stream, the rise in stream level temporarily impedes groundwater inflow into the stream, and, in some cases, flow reverses from ambient conditions such that water flows from the channel into the bed and bank sediments (Figure 1). The regions immediately adjacent to the sediment surface are likely to be flushed and reaerated by the introduction of downward flowing surface water [Hancock and Boulton, 2005]. Evidence of stream water inflow is observable at considerable depth in some streambed sediments [e.g., Arntzen et al., 2006; Squillace, 1996]. By altering the chemical composition of sediment pore water, freshets may stimulate or quench biogeochemical reactions that control nutrient fluxes. Subsequent lowering of stream stage along with groundwater recession following the freshet alter flow direction yet again, and groundwater discharging to the stream reflects the impact of changes in the relative rates of microbially mediated denitrification and groundwater flow rates. Our objective was to evaluate the impact of the transient influx of surface water with a contrasting chemical composition on denitrification rates in streambed sediments underlying the GSI.

[5] Interactions between groundwater and streams are very complex. A first approximation of flow behavior is to represent it as one-dimensional discharge in streambed sediments. Vertical flow is particularly strong just beneath many streams [Chen and Chen, 2003], and vertical ground- 

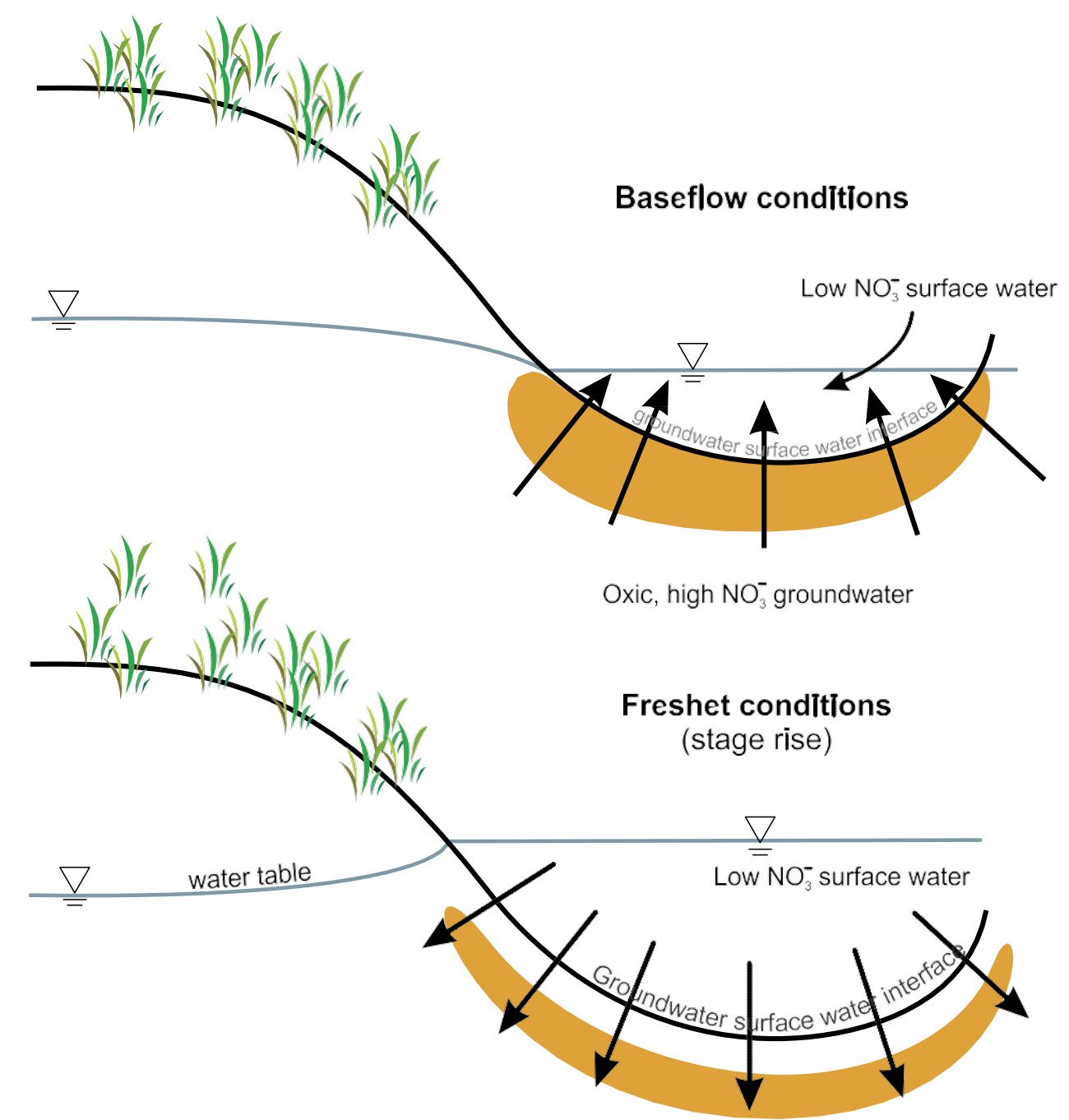

Oxic, high $\mathrm{NO}_{3}^{-}$groundwater

Figure 1. Schematic illustration of groundwater/surface water interaction. The top panel illustrates base flow of low-nitrate surface water resulting from groundwater discharge through anoxic, denitrifying sediments indicated by the shaded region, a region of biologically active, organic-rich sediments below the groundwater/surface water interface (GSI). The bottom panel illustrates the interaction following a rise in stage induced by a freshet: Flow is reversed with oxygenated surface water displacing the anoxic pore water downward into the sediments, temporarily storing stream water in the sediments that will later be released back to the stream during groundwater recession.

water recharge from the surface water has been widely documented [Arntzen et al., 2006; Chen, 2007; Squillace, 1996]. Indeed, vertical flow can be a dominant process in the area beneath streams and riparian zones [Chen, 2007].

[6] To address how biogeochemical processes in streambed sediments vary during hydrological events, we conducted a set of experiments in a sediment core collected from the streambed of Cobb Mill Creek, Virginia. In this study, an intact core was used to study the transport and transformation of $\mathrm{NO}_{3}^{-}$during a simulated transient-flow event. Changes in flow through the sediments such as might occur in the field following a storm were simulated in the laboratory by changing the flow direction through the column and the chemical composition of the influent fied way, the laboratory results to a range of conditions by simulating flow-reversal conditions. Our results indicate that when groundwater is the dominant source of $\mathrm{NO}_{3}$ to the stream, hydrological transients are most likely to result

in an initial decrease in $\mathrm{NO}_{3}^{-}$concentrations in streams during a freshet with a small increase in concentrations during the falling hydrograph. The net effect of a freshet on

$\mathrm{NO}_{3}$ load to the surface stream depends on a balance of physical and biological processes that occur in the sediments immediately below the sediment surface.

solution. A reactive-transport model described results from the experiment well. The model was used, in conjunction with a one-dimensional flow model, to extend, in a simpli- 
2. Materials and Methods

2.1. Field Site at Cobb Mill Creek
[7] Cobb Mill Creek is located near the town of Oyster on Virginia' s Eastern Shore, the southern end of the Delmarva Peninsula located between the Chesapeake Bay and the 
Atlantic Ocean. This is an intensely cultivated region of unconsolidated, sandy Coastal Plain deposits [Mixon, 1985]. Cobb Mill Creek is a second-order, low-gradient (over a stream length of $2.9 \mathrm{~km}$, the streambed elevation drops $10.7 \mathrm{~m}$ ), groundwater-dominated creek. Results of a stream tracer test (A. L. Mills, unpublished data, 2003) indicated that the hyporheic zone is quite small at the site, justifying our approximation of vertical exchange processes. Measurements of groundwater seepage rates consistently show upwelling of groundwater into the stream channel [Galavotti, 2004]. The field site has been extensively characterized for agricultural nitrate contamination and active biogeochemical conditions [Galavotti, 2004] in the streambed sediments where natural organic matter stimulates sufficient indigenous microbial activity to result in denitrification that removes up to $90 \%$ of the nitrate from the discharging groundwater [Galavotti, 2004; Gu et al., 2007].

\subsection{Experimental Approach}

[8] We used an intact core of streambed sediments to simulate the vertical exchange of surface water and groundwater during and following a freshet. The streambed of Cobb Mill Creek is mostly sand with a variable amount of organic matter in discrete sediment samples $(0.05-20 \%$ by weight) imbedded. The organic content is highest (averaged particulate organic carbon content about 3\%) in a layer approximately $25 \mathrm{~cm}$ thick from about the $15-$ to $40-\mathrm{cm}$ depth. Intact cores were obtained from the stream sediments by driving sharpened 5-cm-diameter PVC pipes vertically into the sediments to below the water surface, capping with a rubber stopper, extracting, sealing the bottom, and refrigerating in the lab within $4 \mathrm{~h}$ after collection. Columns were

subsequently cut to obtain a relatively undisturbed section

with a length of approximately $50 \mathrm{~cm}$ that included the

25-cm-thick, organic-matter-rich layer.

[9] The experiment was divided into three phases. During the first $140 \mathrm{~h}$, the column was operated under upflow conditions to simulate base flow with artificial groundwater

(AGW) [Bolster et al., 1999] (amended with $15 \mathrm{mg}$ $\mathrm{NO}_{3}^{-}-\mathrm{NL}^{-1}$ and containing $\mathrm{rv} 8 \mathrm{mg} \mathrm{O}_{2} \mathrm{~L}^{-1}$ ) as the influent.

During the next $40 \mathrm{~h}$, the flow direction was reversed to

simulate groundwater recharge from stream water induced by a sharp rise in stream stage. For this portion of the experi-

ment, the influent was artificial stream water (ASW), a modification of AGW amended to simulate the typical local conditions of low nitrate $(2.0 \mathrm{mg} \mathrm{NO}-\mathrm{N} \mathrm{L}$ ), high $\mathrm{Cl}$

(30 $\mathrm{mg} \mathrm{Cl}^{-} \mathrm{L}^{-1}$ ) well oxygenated ( $\mathrm{rv} 8 \mathrm{mg} \mathrm{O}_{2} \mathrm{~L}^{-1}$ ) surface water. In the final $150 \mathrm{~h}$ of the column experiment, upward flow was resumed with AGW to simulate the return to base flow conditions after the flood wave had passed.

[10] Estimates of the groundwater velocities within the streambed were adapted for the inflow rate of AGW used in the laboratory column experiment. The mean of eight of stream sediments is about $3.6 \mathrm{~cm} \mathrm{~h}^{-1}$ as determined in the laboratory by falling head measurements [Gu, 2007]. The porosity of the streambed sediments was assumed to be 0.35 . Using these values, the specific discharge was calculated to be about $0.54 \mathrm{~cm} \mathrm{~h}^{-1}$. We used a slightly slower rate of $0.35 \mathrm{~cm} \mathrm{~h}^{-1}$ for the inflow rate of AGW. We do not have observations of head changes during flood events, so a specific discharge of $0.5 \mathrm{~cm} \mathrm{~h}^{-1}$ was assumed for the downward flow rate (i.e., the inflow rate of ASW) in the experimental manipulation.

[11] The experimental column extracted from the bed of Cobb Mill Creek was mounted vertically on a rack (see $G u$ et al. [2007] for details and illustration). The intact core was first flushed with AGW for about three pore volumes so that a steady state pore water composition was achieved, as indicated by constant concentrations of chloride and nitrate in the column effluent. During the manipulation of transient flow, pore water samples were collected from the intact sediment core using a 3-mL syringe inserted into each of 12 variably spaced sampling ports positioned from 2 to $5 \mathrm{~cm}$ apart [Gu et al., 2007]. A complete depth profile of $\mathrm{NO}_{3}$ and chloride concentrations was measured every $10 \mathrm{~h}$ during the experiment. Prior to analysis by ion chromatography, water samples were centrifuged at approximately $6900 \mathrm{~g}$ for 20 min to remove particles.

\subsection{Mathematical Model}

\subsubsection{Transport Model}

[12] In order to model the biological reactions that occur within the pore water in the streambed sediments, a onedimensional advection-dispersion model was used:

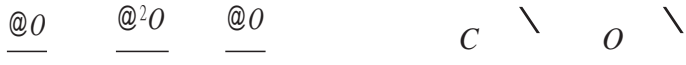

$$
\begin{aligned}
& @ t^{1 / 4 D} @ x^{2}-v @ x-V_{O} X b_{O} \overline{K_{C} p C} \overline{K_{O} p O}
\end{aligned}
$$

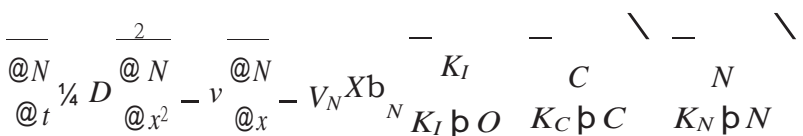

$$
\begin{aligned}
& @ @^{2} C \quad @ \quad \underline{r} \text { - } \\
& @ t^{1 / 4 D} @ x^{2}-v @_{x} \mathrm{p}_{\mathrm{e}} \mathrm{a}^{\left(C-K_{d} C\right.} \\
& C \backslash O \backslash \\
& \mathrm{p}-V_{O} X_{O} \overline{K_{C} \mathrm{pC}} \overline{K_{O} \mathrm{pO}} \\
& -V_{N} X_{N} \frac{K_{I}}{K O C} K^{\prime} K_{N} N_{N} \\
& \frac{d \bar{C}}{d t}{ }^{1 / 4} \text { a }\left(K_{d} C-\epsilon\right) \\
& \text { c } \mathrm{p} \quad{ }_{N} \mathrm{p}
\end{aligned}
$$

where $\mathrm{n}$ is linear pore water velocity $\left[\mathrm{L} \mathrm{T}^{-1}\right], \mathrm{D}$ is the dispersion coefficient $\left[\mathrm{L}^{2} \mathrm{~T}^{-1}\right], \mathrm{O}, \mathrm{N}, \mathrm{C}$ are the $\mathrm{O}_{2}, \mathrm{NO}_{3}^{-}$, and dissolved organic carbon (DOC) concentration, respectively, $\left[\mathrm{M} \mathrm{L}^{-3}\right], \mathrm{V}_{\mathrm{O}}$ and $\mathrm{V}_{\mathrm{N}}$ are the maximum specific uptake rates of the substrate for aerobic respiration and 
measurements of elevation difference between the stream
stage and the water level in a piezometer screened at $\$ .8 \mathrm{~m}$

beneath the stream bottom provided a mean hydraulic head

gradient of 0.15 which was used in the column experiment. The gradient for Cobb Mill Creek is consistent with vertical hydraulic gradient measurements in groundwater discharge zones for other small streams with similar hydrogeological settings [Cey et al., 1999; Harvey and Bencala, 1993; Valett, 1993]. The estimated vertical hydraulic conductivity denitrification, respectively $\left[\mathrm{T}^{-1}\right], \mathrm{K}_{\mathrm{O}}, \mathrm{K}_{\mathrm{N}}$, and $\mathrm{K}_{\mathrm{C}}$ are the half-saturation constants for $\mathrm{O}_{2}, \mathrm{NO}_{3}^{-}$, and DOC, respectively $\left[\mathrm{M} \mathrm{L}^{-3}\right], \mathrm{X}$ is the biomass concentration of facultative

denitrifers $\left[\mathrm{M} \mathrm{L}^{-3}\right], \overline{\mathrm{K}_{\mathrm{I}}}$ is the inhibition constant for that substance $\left[\mathrm{M} \mathrm{L}^{-3}\right], C$ is the particular organic carbon content $\left[\mathrm{M} \mathrm{M}^{-1}\right], \mathrm{b}$ is the uptake coefficient of the solutes for biodegradation process, $\mathrm{K}_{d}$ is the distribution coefficient $\left[\mathrm{L}^{3}\right.$ $\left.\mathrm{M}^{-1}\right]$, a is first-order mass transfer coefficient $\left[\mathrm{T}^{-1}\right], r$ 

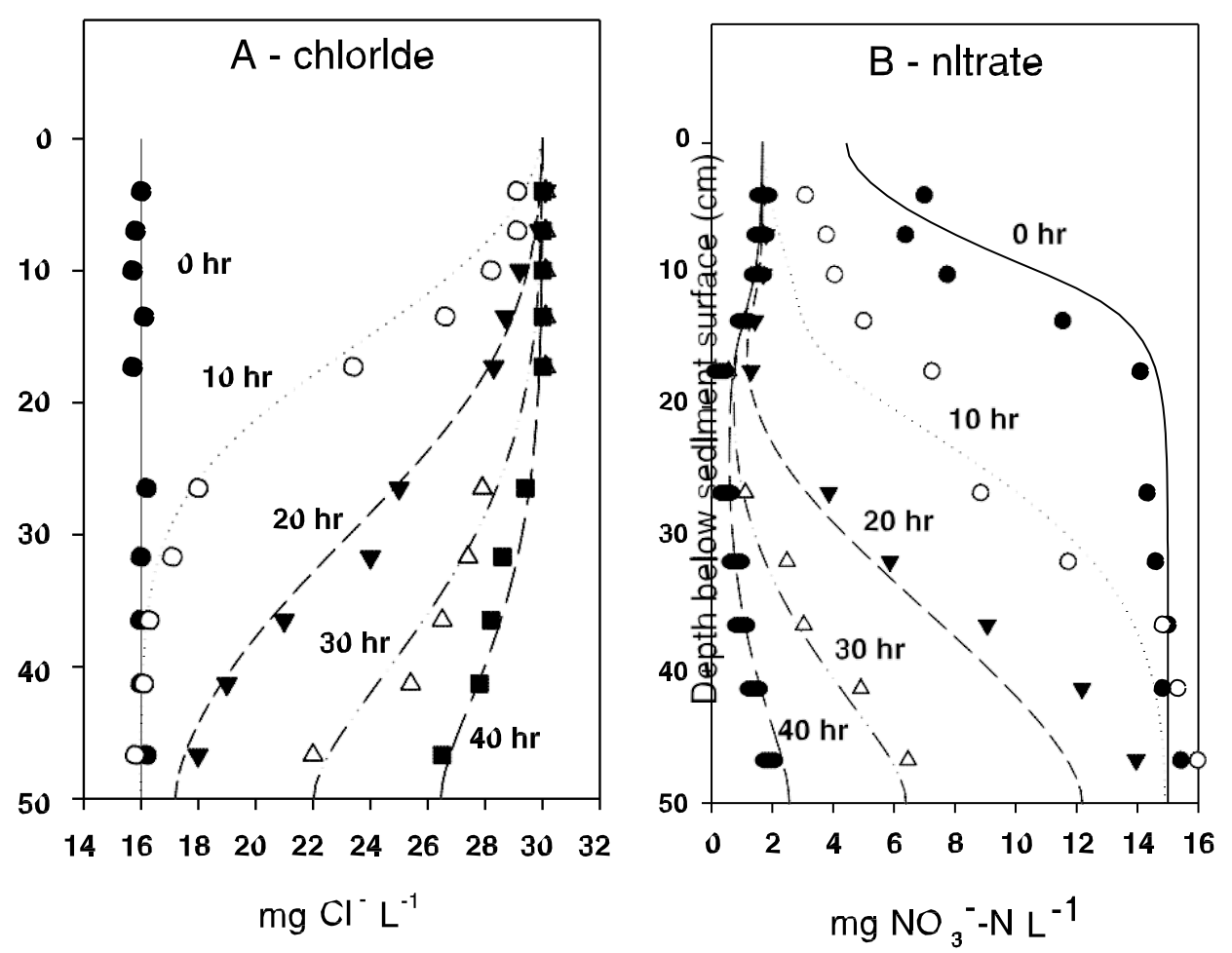

Figure 2. Solute concentrations observed (symbols) in the intact sediment core during laboratory artificial stream water (ASW) infiltration experiment. Model simulations (lines) describe the $\mathrm{Cl}^{-}$and $\mathrm{NO}_{3}{ }^{-}-\mathrm{N}$ profiles well.

is the bulk density $\left[\mathrm{M} \mathrm{L}^{-3}\right]$, and $\mathrm{e}$ is the porosity (dimensionless). Complete details of the model development are described by Gu et al. [2007] and Gu [2007]. A Dirichlet condition (constant groundwater concentration) was applied to the base of the column (i.e., the beginning of the flow path), while a Cauchy (nondispersive flux) condition was applied to the top of the column (i.e., the outlet of the column where pore water exits across the GSI).

Table 1. Microbiological and Physical Parameters and Boundary Conditions Used in the Simulation of Column Experiments

\begin{tabular}{|c|c|c|}
\hline & $\mathrm{O}_{2}$ & $\mathrm{NO}_{\overline{3}}$ \\
\hline \multicolumn{3}{|c|}{ Microbiological Parameters } \\
\hline Maximum specific growth rate $\left(\mathrm{m}_{\max }\right), \mathrm{h}^{-1}$ & $1.9^{\mathrm{a}}$ & $1.6^{\mathrm{a}}$ \\
\hline Half-saturation constant of electron acceptors, $\mathrm{mg} \mathrm{L}^{-1}$ & $0.2^{\mathrm{b}}$ & $2^{\mathrm{a}}$ \\
\hline Half-saturation constant of electron donor, $\mathrm{mg} \mathrm{L}^{-1}$ & $1^{\mathrm{b}}$ & $1^{\mathrm{b}}$ \\
\hline b, uptake coefficient & $2^{b}$ & $2^{b}$ \\
\hline a, mass transter coetticient ot particulate organic carbon, $\mathrm{n}$ - & $5 \times 10^{-5(c)}$ & $5 \times 1 U^{-(c)}$ \\
\hline $\mathrm{K}_{\mathrm{d}}$, distribution coefficient of dissolved organic carbon, $\mathrm{L} \mathrm{kg}^{-1}$ & $0.01^{\mathrm{b}}$ & $\begin{array}{c}50^{\mathrm{c}} \\
0.01^{\mathrm{b}}\end{array}$ \\
\hline Inhibition constant of oxygen, mg I & & $0.01^{\circ}$ \\
\hline
\end{tabular}

Longitudinal grid spacing, $\mathrm{cm}$

Physical Parameters

Column length, $\mathrm{cm}$

Effective porosity

Longitudinal dispersivity, $\mathrm{cm}$

Linear velocity, $\mathrm{cm} \mathrm{h}^{-1}$

Time step size, $\mathrm{h}$

$\begin{array}{cc}1 & 1 \\ 50 & 50 \\ 0.30^{\mathrm{d}} & 0.30^{\mathrm{d}} \\ 3^{\mathrm{d}} & 3^{\mathrm{d}} \\ 1.4^{\mathrm{d}} & 1.4^{\mathrm{d}} \\ 0.2 & 0.2\end{array}$

\begin{tabular}{|c|c|c|}
\hline Boundary Conditions & Discharge & Recharge \\
\hline $\begin{array}{l}\mathrm{O}_{2}, \mathrm{mg} \mathrm{L}^{-1} \\
\mathrm{NO}_{3}^{-}-\mathrm{N}, \mathrm{mg} \mathrm{L}^{-1}\end{array}$ & $\begin{array}{c}8 \\
15\end{array}$ & $\begin{array}{l}8 \\
2\end{array}$ \\
\hline $\begin{array}{l}\text { Dissolved organic carbon, } \mathrm{mg} \mathrm{L}^{-1} \\
\mathrm{Cl}^{-}, \mathrm{mg} \mathrm{L}^{-1}\end{array}$ & $\begin{array}{c}0 \\
16\end{array}$ & $\begin{array}{c}0 \\
30\end{array}$ \\
\hline
\end{tabular}

\footnotetext{
${ }^{\mathrm{a}} \mathrm{Gu}$ et al. [2007].
}

${ }^{b}$ Chen et al. [1992], Doussan et al. [1997], Kindred and Celia [1989], Kinzelbach et al. [1991], and MacQuarrie et al. [1990].

${ }^{\circ}$ MacQuarrie et al. [2001] and Robertson and Cherry [1995].

${ }^{\mathrm{d}}$ Determined by inverse transport modeling of $\mathrm{Cl}^{-}$using CXTFIT [Toride et al., 1995]. 


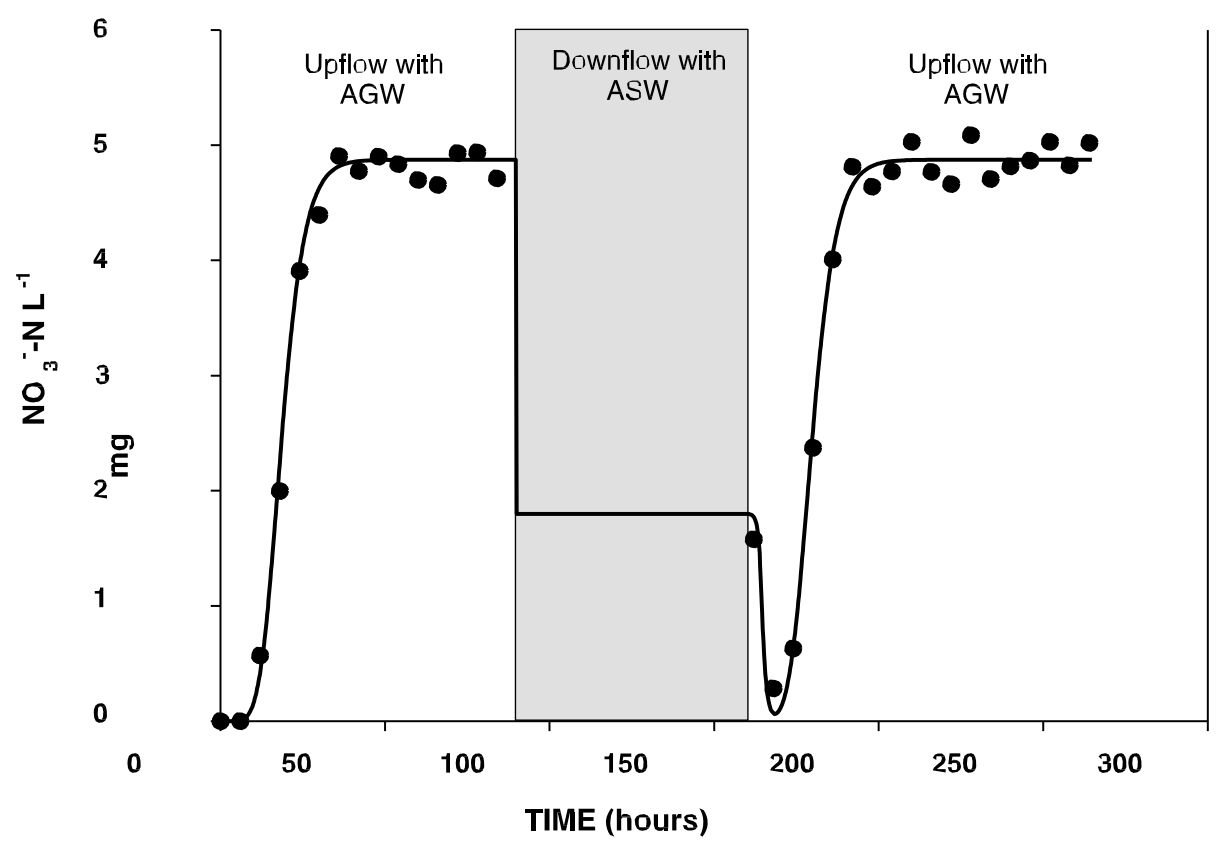

Figure 3. Temporal variation of $\mathrm{NO}_{3}-$ concentration at the end of the groundwater flowpath (i.e., the

column outlet). The reverse flow lasted from 90 to $160 \mathrm{~h}$. Laboratory observations (points) and model simulation (line) are illustrated. Note that during downward flow there is no observation of $\mathrm{NO}_{3}-$ concentration of water exiting the column; rather, the ASW concentration of $\mathrm{NO}_{3}$ is entering the column.

\subsubsection{Flow Model}

[13] In Cobb Mill Creek itself (and in other streams), the complete instantaneous flow reversal effected in the laboratory does not occur; rather, head changes occur gradually in accordance with the passing flood wave. We used a simple one-dimensional model to simulate the head changes, and hence changes in fluxes across the GSI that occur as a result of the passage of a flood wave and subsequent dissipation of groundwater head.

[14] We computed the propagation of a pressure wave (hydraulic head) into the streambed sediments induced by passage of a freshet using

$$
\begin{aligned}
& \text { @h@ @ h } \\
& @ t^{-D_{h}}{\overline{@ x^{2}}}^{1 / 40 ;}
\end{aligned}
$$

where $h(x, t)$ is the hydraulic head $(\mathrm{L}) ; D_{h}$ is hydraulic diffusivity (hydraulic conductivity divided by specific storage; $\left.\mathrm{L}^{2} \mathrm{~T}^{-1}\right) ; x$ represents the (vertical) space coordinate $(\mathrm{L})$; and $t$ is the time coordinate. This approach to estimate pressure has been found useful for subseabed sediments [e.g., Wang and Davis, 1996]. The boundary conditions constraining equation (2) are $0: \cdots x::: \mathrm{x}$ where $\mathrm{x}$ is the thickness of the sediments through which pore water flows vertically (L); $0<t ; h(0, t)=H(t)$, where $H(t)$ represents the stream stage which is a time-dependent boundary condition at the end of the flow path (i.e., GSI or top of the column) (L); $h(x, 0)=h_{0}(x)$ where $h_{0}(x)$ is the initial head (L) from the steady state simulation; and $h(\mathrm{x}, t)=h_{0}(\mathrm{x})$.

In this work we took $\mathrm{x}$ to be $100 \mathrm{~m}$ to set a constant head condition effectively at ' 'infinity.' ' An estimate for hydraulic diffusivity is also needed to calculate groundwater flows. Values for $D_{h}$ of about $10^{-1} \mathrm{~m}^{2} \mathrm{~s}^{-1}$ have been reported for river sediments [e.g., Barlow et al., 2000] and values of rv2 $\times 10^{-6} \mathrm{~m}^{2} \mathrm{~s}^{-1}$ have been reported for subglacier sediments [e.g., Fischer et al., 2001]. For illustrative purposes, we use the logarithmic average of these values, $4.5 \times 10^{-4} \mathrm{~m}^{2} \mathrm{~s}^{-1}$, and subsequently report results for a range of values. The time-dependent head boundary condition, $H(t)$, was represented by a hypothetical stage hydrograph. We assumed a fixed, asymmetrical shape of flood-stage hydrograph by setting the time of the flood crest, $t_{c}$, at $1 / 4$ of the duration of the flood wave. According to Cooper and Rorabaugh [1963], the shapes of flood-wave stage hydrographs $H(t)$ can be approximated by

$$
H \text { ðtp } 1 / 4 N h_{0} e^{-\mathrm{w} t} \partial 1-\cos w t \mathrm{P} 0 \cdots: t::: \mathrm{t} ;
$$

where $h_{0}$ is the maximum rise in stage, $t$ is the time since the beginning of the flood wave, $t$ is the duration of the wave, $\mathrm{w}=2 \mathrm{p} / \mathrm{t}$, and

$$
N^{1 / 4} \frac{1}{e^{-\mathrm{p}=2}}
$$

is a constant that scales all the hydrographs, regardless of the duration of each storm, to peak at the same height, $h_{0}$.

[15] Under the stated assumptions, the specific discharge in the direction of increasing $\mathrm{x}$, where $\mathrm{x}$ is elevation, is, according to Darcy' s law,

$$
q^{1 / 4-K} @ @_{x}
$$$$
\text { OP }
$$

where $K$ is the vertical hydraulic conductivity of the sediment and $q$ is specific discharge $\left(\mathrm{L} \mathrm{T}^{-1}\right)$ across the GSI. 


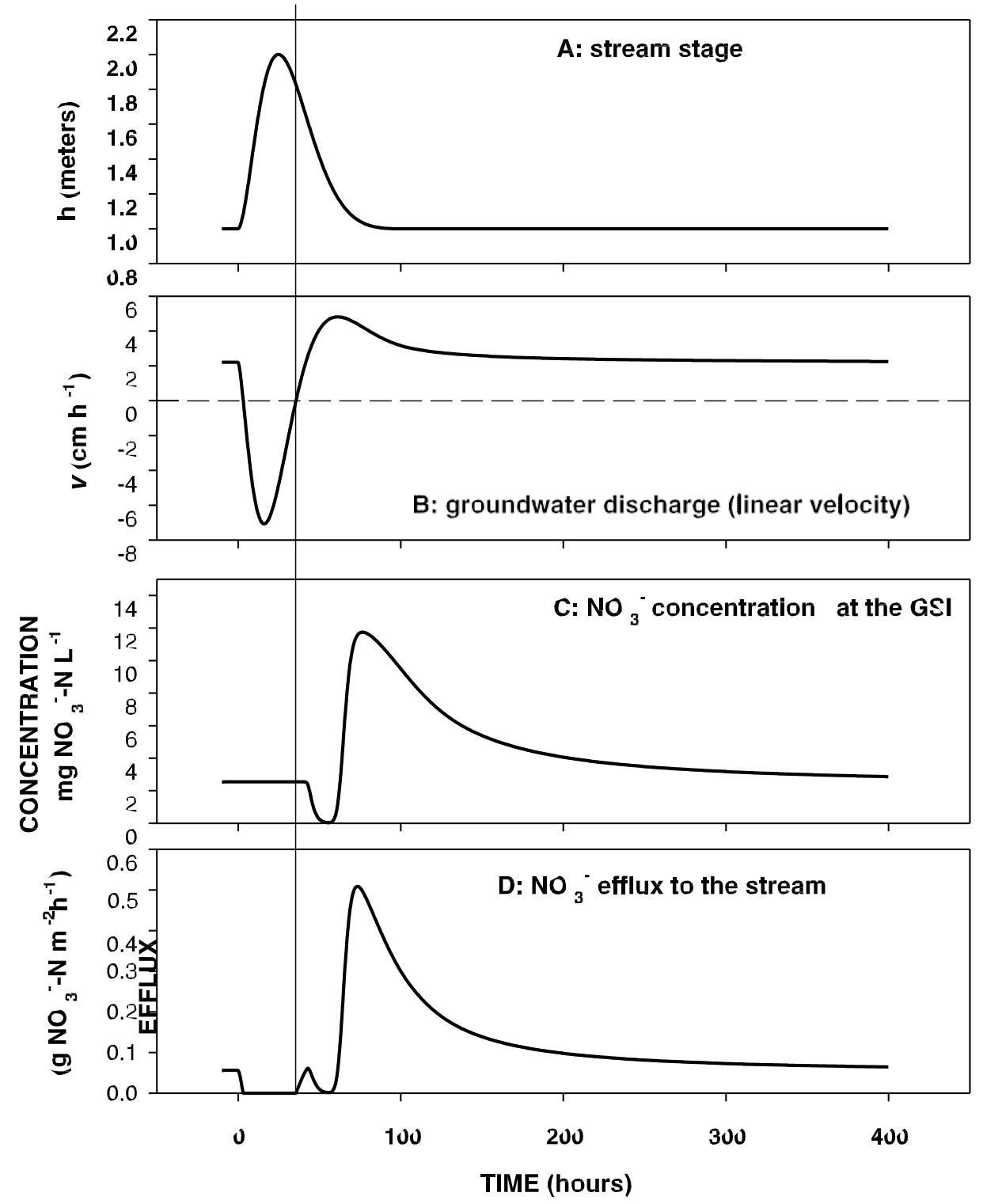

Figure 4. Simulated temporal impact of a hypothetical storm with $\mathrm{h}_{0}=1 \mathrm{~m}$. Time 0 represents the start time of a rainfall event.

Positive values of $q$ represent discharge to the stream, and negative values represent recharge from the stream.

[16] A range of scenarios were simulated for the analysis of the characteristics of exchanges between stream water and groundwater. Two parameters, $\mathrm{t}$ and $\mathrm{h}_{0}$ in equation (3), control the stage variations and therefore determine the direction and magnitude of groundwater discharge, $v$, in equation (5). The duration of a flood wave, $t$, ranges from hours to days and depends on the size and other physical characteristics of the basin as well as on the intensity of rainfall [Martinec, 1985]. For small- and medium-sized drainage basins, $t$ may vary from a few hours to a few days; for large drainage basins, $\mathrm{t}$ may be as long as a few weeks [Singh, 1968]. In this study, we used the following scenarios: The duration of the flood wave, $t$, ranged from 0.5 to $4 \mathrm{~d}, t_{c} / \mathrm{t}=0.25$, and the maximum rise in stage, $h_{0}$, varied from 0.1 to $1 \mathrm{~m}$. The diffusivity of the sediments is the other important parameter. We considered a range of values for $D_{h}$ from $10^{-4}$ to $10^{-1} \mathrm{~m}^{-2} \mathrm{~s}^{-1}$. Although smaller values for hydraulic diffusivity are possible [e.g., Fischer et al., 2001], values for streambed sediments are likely to be in the vicinity of $10^{-2} \mathrm{~m}^{2} \mathrm{~s}^{-1}$ or even higher [e.g., Barlow et al., 2000].

\section{Results}

\subsection{Experimental Results}

[17] Transient changes in water chemistry were observed during the 6 days of the column experiment. During the initial period of upflow, a ' 'pre-event' ' steady state was achieved, represented by the $\mathrm{Cl}^{-}$and $\mathrm{NO}_{3}^{-}$profiles at $\mathrm{O} \mathrm{h}$ in Figures $2 \mathrm{a}$ and $2 \mathrm{~b}$. The lack of an initial $\mathrm{Cl}^{-}$concentration gradient is consistent with the assumption that $\mathrm{Cl}^{-}$is a conservative solute, whereas $\mathrm{NO}_{3}^{-}$concentration decreases near the column outlet due to denitrification. The applied flow reversal led to higher concentrations of $\mathrm{Cl}^{-}$and lower concentrations of $\mathrm{NO}_{3}^{-}$in interstitial water, as the sediment pore water (initially AGW) was successively replaced by 


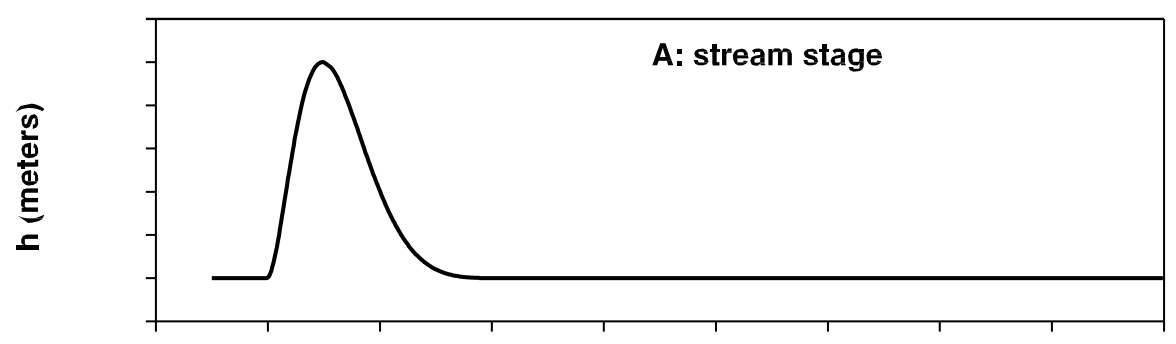

ז 2.0

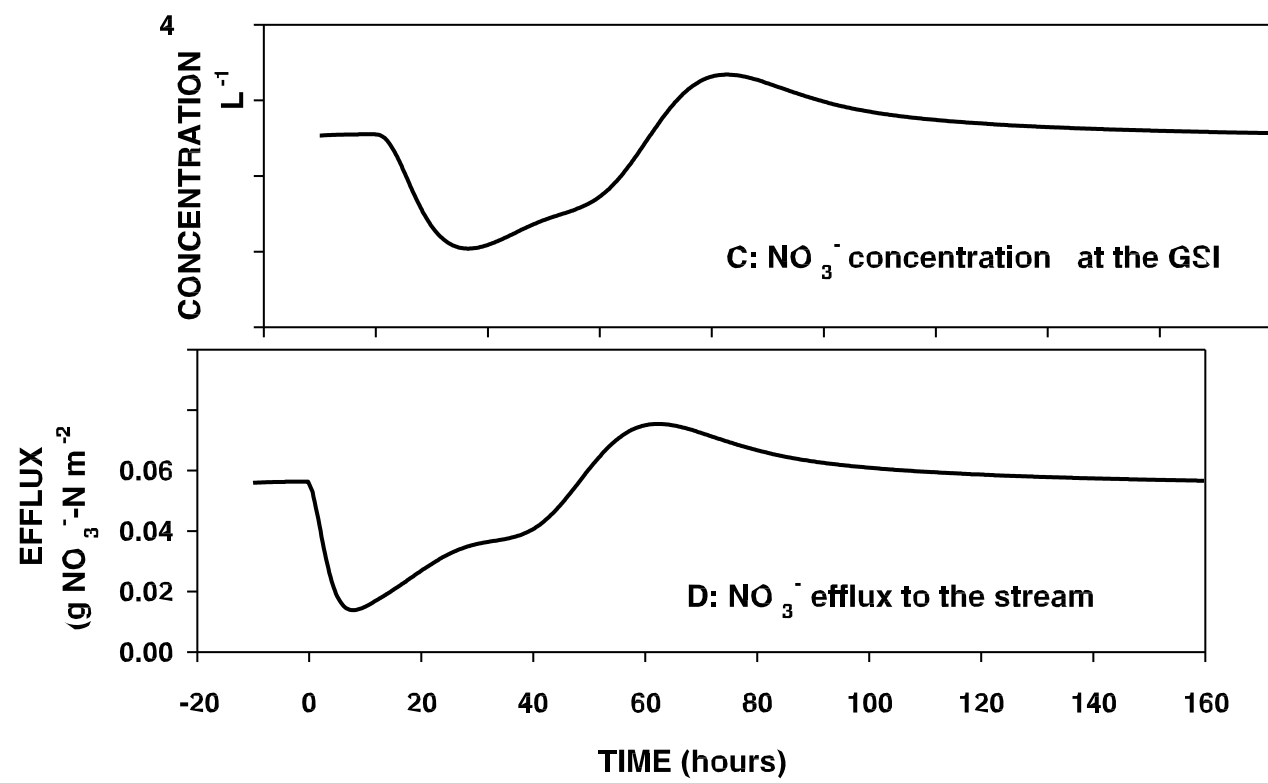

Figure 5. Simulated temporal impact of a hypothetical storm with $h_{0}=0.1 \mathrm{~m}$. Time 0 represents the start time of a rainfall event.

infiltrating water (ASW) from the surface. Throughout the downflow period, the $\mathrm{Cl}^{-}$concentration front migrated downward in the column (Figure 2a). Prior to the infiltration of surface water into the sediment, the $\mathrm{NO}_{3}=\mathrm{N}$ concentration exhibited a sharp gradient from $\mathrm{rv} 15 \mathrm{mg} \mathrm{L}^{-1}$ in the deep portion of the sediment to $<7 \mathrm{mg} \mathrm{L}^{-1}$ at $<10 \mathrm{~cm}$ below the sediment surface. Soon after flow was reversed, the pore water $\mathrm{NO}_{3}$ in the upper portion of the column decreased and_approached the $\mathrm{NO}_{3}$ concentration of ASW, while $\mathrm{NO}_{3}$ concentration in the undisturbed groundwater (bottom portion) remained high. After $40 \mathrm{~h}$ of surface water downwelling, the pore water- $\mathrm{NO}_{3}$ profile was relatively uniform from top to bottom and approximated the $2.0 \mathrm{mg} \mathrm{NO}_{3}^{-}-\mathrm{N} \mathrm{L}^{-1}$ concentration in the surface water except for a lower concentration in the region from $15-$ to $40-\mathrm{cm}$ depth that coincided with a layer relatively rich in particulate organic carbon (POC), which consequently is the zone of greatest concentration to lower levels than that in ASW was apparent in all profiles for times greater than $20 \mathrm{~h}$.

3.2. Modeling Results

3.2.1. Calibration of the Transport Model

[18] Chloride was used as a conservative tracer to estimate the hydrodynamic parameters for the column (Table 1). Several of the kinetic parameters in Table 1 were selected from ranges of values reported in the literature. Kinetic parameters to which the model was most sensitive as

determined by Gu et al. [2007] were estimated by model calibration, 1.e., the sum of squares errors between the

calculated and observed values was minimized. A comparison between the calculated and observed data for the transient state during ASW infiltration indicated that chloride and nitrate profiles were well reproduced by the model (Figure 2).

3.2.2. Concentration of $\mathrm{NO}_{3}{ }^{-}$at the Sediment Surface 
1.12

biological activity. The deterease in $\mathrm{NO}_{3}$ below the level 1.08

contained in ASW is presup.o6 to be a result of denitrification of the ASW once oxygen was depleted. This decrease in $\mathrm{NO}_{3}^{-}$

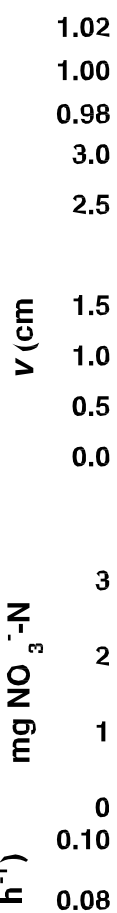

-N concentrations at the top of the column [19] $\mathrm{NO}_{3}$

(Figure 3) changed from the initial steady state value of

B: groundwater discharge (linear velocity) 


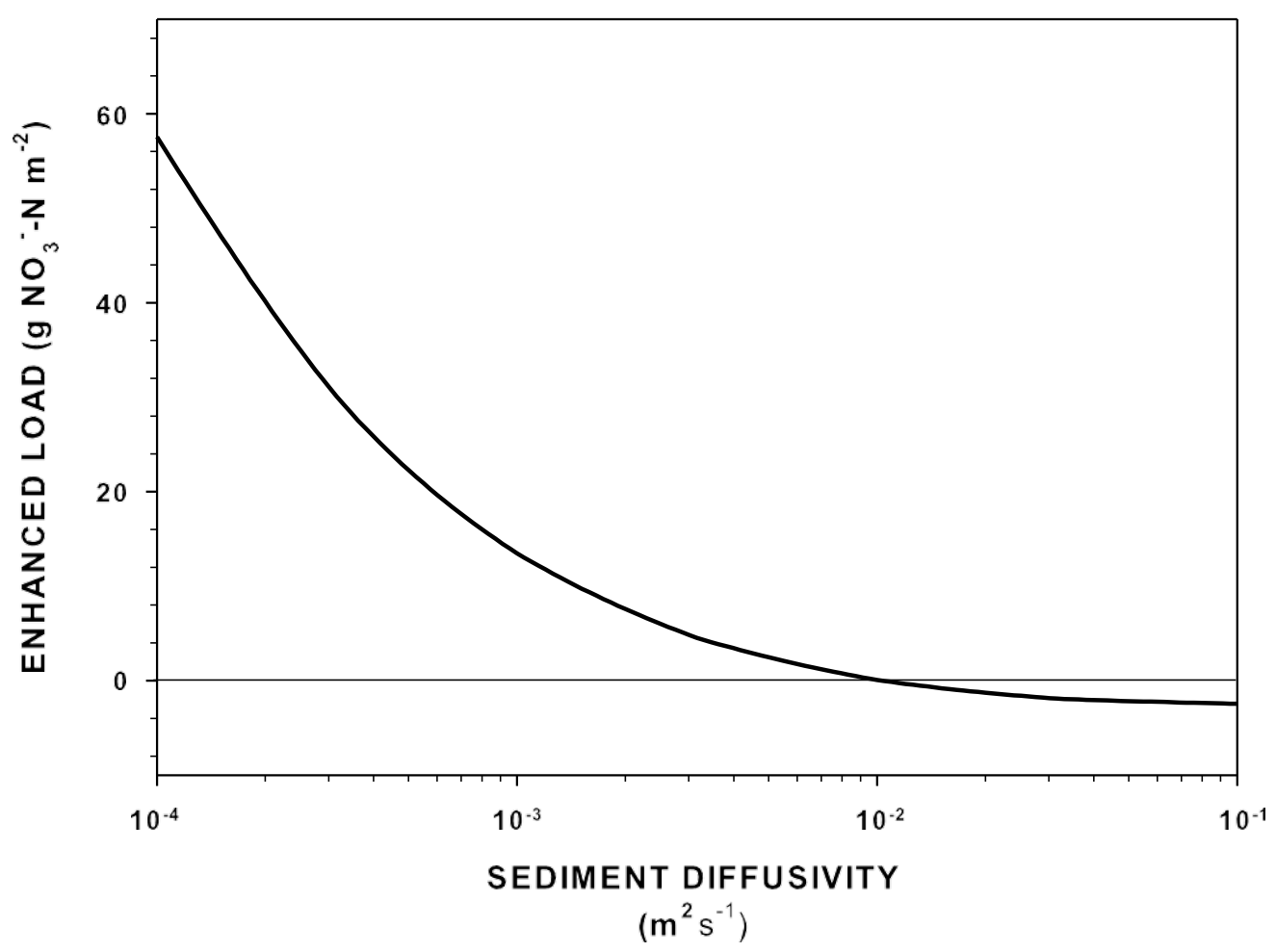

Figure 6. The relationship of total net enhanced $\mathrm{NO}_{3}=\mathrm{N}$ load resulting from the freshet of $\mathrm{h}_{0}=1 \mathrm{~m}$ and $\hat{\mathrm{o}}=100 \mathrm{~h}$ as compared with base flow condition. Negative values indicate a reduction of load.

about $5 \mathrm{mg} \mathrm{L}^{-1}$ observed during upflow to the ASW

concentration of $2.0 \mathrm{mg} \mathrm{NG}-\mathrm{N} \mathrm{L}^{-1}$ throughout the period

of flow reversal. The concentration then dropped sharply as upflow was restarted before returning to the original steady

state value. The breakthrough curve of $\mathrm{NO}_{3}{ }^{-}$was well

described by the numerical model (Figure 3). The rapid return to pre-event conditions suggests that the microbes carrying out denitrification were not adversely affected by the flow manipulations.

3.2.3. Simulated Episodic Hydrochemistry

[20] The flow model (equations (3) - (5)) was used to calculate discharge from and recharge rates to the sediment

for a freshet with $h_{0}=1 \mathrm{~m}$ and for another with $h_{0}=$

$0.1 \mathrm{~m}$. For the larger of the simulated flood waves, the flow reversal leads to maximum recharge rates of about

$7 \mathrm{~cm} \mathrm{~h}^{-1}$ (Figure 4a) with discharge rates following

passage of the flood wave reaching about $5 \mathrm{~cm} \mathrm{~h}^{-1}$

(Figure $4 \mathrm{~b})$. Recall that the negative $\mathrm{n}$ represents stream infiltration during the storm, and the positive $\mathrm{n}$ indicates the return flow of the infiltrated water to the stream that begins in the later period of the flood wave and continues into the postflood period. The return flow is slower but

lasts much longer than the period of stream infiltration. The largest rate of stream infiltration occurs earlier than the peak stage, and the largest rate of the return flow occurs close to the end of the recession period (Figure 4b).
After the streamward gradient was reestablished, i.e., during groundwater discharge, the short lag prior to the decrease in concentration reflects return of stored water that resided in the shallow sediments for too short a time to permit

denitrification. Then, the concentration of $\mathrm{NO}_{3}{ }^{-}$dropped

to its lowest level and then increased, ultimately exceeding the prestorm concentration. The concentration then gradually returned to the prestorm level, but the pulse release lasted more than a week.

[22] The $\mathrm{NO}_{3}^{-}$flux into the stream was shut off during the stream water infiltration (Figure 4d). After groundwater discharge was reestablished, there was a small pulse export

of $\mathrm{NO}_{3}$ due to the release of the stored water that had not undergone denitrification. The flux decreases again, reflecting the discharge of water stored for an adequate time to allow denitrification. The peak $\mathrm{NO}_{3}$ efflux represents the discharge of high- $\mathrm{NO}_{3}^{-}$groundwater under high rates of discharge (Figure 4b) that had passed through the organic rich layer (the most biologically active zone) too quickly to allow efficient denitrification. The peak efflux was as much as 10 times as high as the base flow efflux. The $\mathrm{NO}_{\overline{3}}$ efflux returns to pre-event levels in the same timeframe as $\mathrm{NO}_{3}-$

[21] The calculated flow rates were used to drive the 
concentrations (Figure 4c).

[23] A storm with less intensity showed different effects (Figure 5). As a relatively small flood wave passed in the reactive-transport model derived from the laboratory experi-

ments. Concentration of $\mathrm{NO}_{3}^{-}$at the GSI (analogous to the

end of the flow path through the sediments, either in the stream or in the laboratory column) is the stream water concentration during the flow reversal, i.e., during recharge from the stream to the sediment pore water (Figure 4c). stream (40 h with 0.1-m stage rise, Figure 5a), the streamward gradient decreased but without a flow reversal (Figure 5b). The $\mathrm{NO}_{3}$ concentration at the GSI (Figure 5c) decreased accordingly due to the longer residence time of groundwater in the streambed sediments. As a result, the $\mathrm{NO}_{\overline{3}}^{-} \mathrm{N}$ efflux to the stream was significantly reduced, followed by a relatively small pulse release of stored water and solute (Figure 5d). 

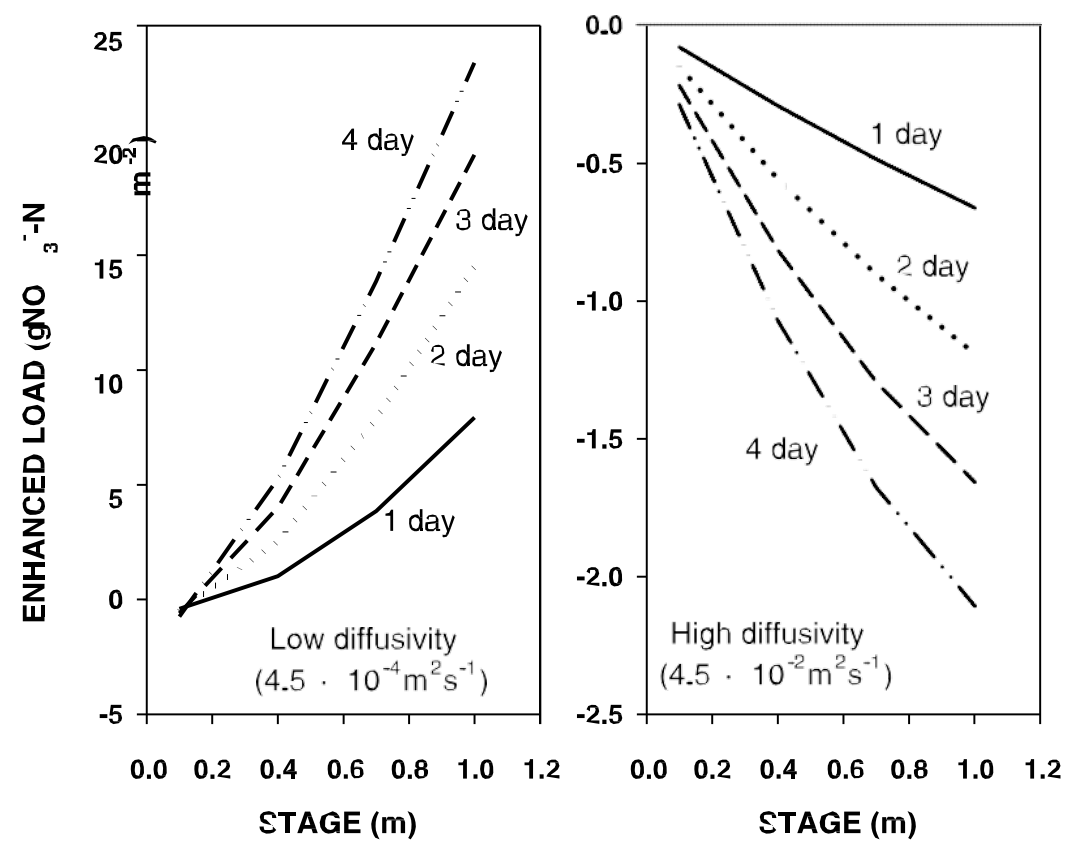

Figure 7. Relative to base flow conditions, $h_{0}=0$, in a sediment with diffusivity of $4.5 \times 10^{-2} \mathrm{~m}^{2} \mathrm{~s}^{-1}$, the value used in all previous simulations, the response of enhanced $\mathrm{NO}_{3}{ }^{-}$flux ${ }_{1}$ as the function of

hydrograph peak and duration for (a) sediment diffusivity $=4.5 \times 10^{-4} \mathrm{~m}^{2} \mathrm{~s}^{-}$and (b) sediment diffusivity $=4.5 \times 10^{-2} \mathrm{~m}^{2} \mathrm{~s}^{-1}$.

[24] The total net change in $\mathrm{NO}_{3}^{-}$load can be calculated as the difference between the total reduction in load (storage) and the total enhanced load (pulse release) by integrating the flux curve (Figures $4 \mathrm{~d}$ and $5 \mathrm{~d}$ ) above and below the base flow

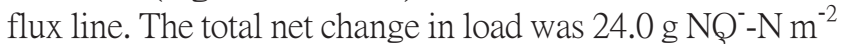
(increased) for the 1-m flood (Figure 4) and was $-0.41 \mathrm{~g}$

$\mathrm{NO}_{3}^{-}-\mathrm{N} \mathrm{m}^{-2}$ (decreased) for the 0.1-m flood (Figure 5).

[25] The transient flux of $\mathrm{NO}_{3}^{-}$also depends on sediment diffusivity, which describes the extent and speed of stream-groundwater interaction and the amount of water stored in the sediments as the flood wave passes. The results above (Figures 4 and 5) are for a hydraulic diffusivity of $4.5 \times 10^{-4} \mathrm{~m}^{2} \mathrm{~s}^{-1}$. The groundwater model was solved for the same freshet conditions but with sediment diffusivities ranging from $10^{-4}$ to $10^{-1} \mathrm{~m}^{-2} \mathrm{~s}^{-1}$. The

total load of $\mathrm{NO}_{3}^{-}$decreases with increasing sediment diffusivity (Figure 6).

[26] The response of total net $\mathrm{NO}_{3}^{-}$loading to passage of a freshet depends on the magnitude and duration of the event and on the sediment diffusivity (Figure 7). For a relatively small diffusivity, which indicates a relatively small amount of stored water due to the transient pressure

changes, the enhanced load of $\mathrm{NO}_{3}^{-}$increases with the hydrograph peak and duration (Figure 7a). For a relatively large diffusivity, the load is reduced (negative values) with a trend to more negative values with hydrograph peak and duration (Figure $7 b$ ). abundance of organic carbon in the sediments. In such systems, the main factor controlling the extent of nitrate reduction in streambed sediments under base flow conditions is the ratio of the timescale for groundwater flow (a measure of residence time in the sediments) to the timescale of the rate of microbial reaction $[G u$ et al.,

2007; Ocampo et al., 2006]; this ratio is referred to as a

Damkohler number (equal to $V_{N} L / v$, where $L$ is the column

length and the other terms are defined in equation (1)). The passage of a freshet in these systems potentially can have several effects. The increased pressure head at the GSI during the passage of a flood wave will decrease and perhaps reverse the head gradient at the GSI leading to increased residence time of groundwater in the sediments while the head in the stream is elevated. In the case where

the gradient is actually reversed and stream water enters the shallow subsurface, there are additional effects. First, the influx of stream water with a relatively low concentration of

$\mathrm{NO}_{3}$ would dilute the near-surface groundwater. Second,

the influx of highly oxygenated water from the stream into the sediments could stop the denitrification process, at least temporarily. Finally, the stream water that is stored

in the sediments during the passage of the flood wave

\section{Discussion}

[27] Several aspects of the interaction of water flowing in a stream channel with the streambed sediments determine the nitrate efflux from groundwater to the stream. Cobb Mill Creek 
is typical of many streams draining agricultural and forested catchments in the temperate zone in that there is an would be released during the period of groundwater recession following the decline in head in the stream. The resulting ' 'pulse' of groundwater flow to the stream following the freshet is concomitant with a reduction in the residence time the groundwater spends within the biologically active streambed sediments.

[28] Dilution of groundwater by surface water during flow reversal clearly is an important process in our laboratory experiments. The $\mathrm{NO}_{3}$ concentration in the pore water was significantly reduced from the higher concentration in AGW during ASW infiltration (Figure 2). This process was also documented in a field study by Pinay et al. [1998] in 
which a large portion of seasonal $\mathrm{NO}_{3}-$ decrease was

attributed only to dilution by $\mathrm{NO}_{\overline{3}}$-poor river water. However, our results show that pure dilution is not sufficient to describe the downwelling process during a freshet. Although pore water contained successively greater amounts of surface water during ASW infiltration, observed $\mathrm{NO}_{3}-\mathrm{N}$ concentrations were still rv10 - 80\% lower than those predicted from

dilution alone as inferred from the $\mathrm{Cl}^{-}$profile (Figure 2).

Compared with the uniform decline exhibited in the $\mathrm{Cl}^{-}$

profile, $\mathrm{NO}_{3}^{-}$concentrations are reduced below that of the

ASW beginning at about the $15-\mathrm{cm}$ depth, corresponding to

the location of a POC-rich layer [Gu et al., 2007]. The decline in $\mathrm{NO}_{3}$ at this depth is believed to be related to the microbial activities (i.e., denitrification) within this layer (Figure 2).

[29] Despite the fact that both the groundwater and the stream water are oxic, substantial denitrification occurs as the water passes through the sediments in either direction. The consumption of $\mathrm{O}_{2}$ by oxidative degradation of labile organic matter within the organic-rich portion of the streambed sediments (shaded region in Figure 1) exceeded the rate of oxygen replenishment from either infiltrating ASW or discharging AGW. Biogeochemical conditions favorable for denitrification persisted in the organic-rich, water-saturated sediments underlying the zone into which surface water had intruded. Even in some extreme cases when the infiltrated oxygen does quench denitrification (i.e., very rapid infiltration, thus low Damkohler number), the pre-event anaerobic condition will be rebuilt quickly after streamward flow is recovered (Figure 3) due to the abundance of organic carbon abetted by the fact that denitrifing bacteria are usually facultative and able to adapt quickly to alternating oxic and anoxic conditions.

[30] The change in the effluent concentration of $\mathrm{NO}_{3}$ over time following passage of a freshet reflects the two sources of water to the stream: (1) stream water that had been temporarily stored in the pores of the streambed sediments during flow reversal and (2) deeper groundwater. Initially, return flow entering the stream has a low concen-

tration of $\mathrm{NO}_{3}^{-}$reflecting the original source stream water.

The concentration increases with time until the stored water is fully discharged from the subsurface. During extended return-flow conditions, concentrations in the discharge exceed those in pre-storm discharge; the elevated head gradient causes higher flow velocity, and the high- $\mathrm{NO}_{3}$ groundwater experiences a shorter residence time in the organic-rich layer of sediments. This sequence would be expected in Cobb Mill Creek where the stream water has a

lower $\mathrm{NO}_{3}^{-}$concentration than the groundwater. In cases

where the solute concentration is higher in the surface water than in the groundwater, the reverse would occur, with

elevated concentrations early in the return flow and declining concentrations with time as observed in Cedar River, Iowa [Squillace et al., 1993].

[31] Taking our experimental results as representative of denitrification dynamics during a freshet in a stream like while for large events, the residence time is of the order of a

few weeks. The greater residence time (as described by a high Damkohler number) is adequate to support substantial biological reduction [Gu et al., 2007]. The stream water that enters the sediment during the freshet slowly seeps back into the surface stream during the postflood period as hydraulic gradients return to normal. Because of the bio-

logical removal of $\mathrm{NO}_{3}$ in the stored water, the returning

water is more dilute than the stream water with respect to

$\mathrm{NO}_{3}^{-}$. The outflow gradually returns to the relatively high

postevent steady state $\mathrm{NO}_{3}^{-}$concentration in small storms

(Figure 5c). Consequently, there is an attenuation of nitrate load to the stream because of denitrification of stored water with increased residence times during the diminishment or reversal of groundwater flow to the stream.

[32] Enhanced solute flux caused by the release of stored water is also possible during the later period of return flow. During relatively large events in which the hydraulic head rises to higher values and stream water is stored in the sediments, the stored water initially released as stream stage drops is discharged at a faster rate than is observed at base flow, and groundwater discharge gradually declines back to pre-event base flow velocity (Figure $4 \mathrm{~b}$ ). The model-simulated return flow for a stream rise of $1 \mathrm{~m}$ indicated groundwater discharge to the stream at rates as high as twice that during base flow with elevated discharge rates lasting for about $12 \mathrm{~d}$ (Figure 4b). Similarly, Squillace [1996] observed that during the first 3 weeks following a flood, bank storage caused groundwater discharge to the river to increase by a factor of 5 compared with pre-event conditions, and somewhat elevated discharge persisted for about an additional 5 weeks.

[33] For a relatively small storm, the ' 'release pulse' ' is negligible, and storage of water and increased retention time induce a net reduction in $\mathrm{NO}_{3} 3$ loading. For a relatively large storm, the ' 'release pulse' ' can be substantial, leading to a net increase in $\mathrm{NO}_{3}$ loading as less denitrification occurs in groundwater with shorter residence time. Our simulation results suggest that the sediment hydraulic properties play

an important role in transient $\mathrm{NO}_{3}$ - delivery by affecting the

rate and volume of stream infiltration and return flow. Low sediment diffusivities lead to small amounts of water stored but to high streamward gradients following a flood, with the reverse being true for high diffusivities. Therefore net increases in nitrate loading to a stream occur for sediments with low diffusivities, and net decreases in nitrate loading to a stream occur for sediments with high diffusivities (Figure 6). For low diffusivity, the primary

effect of increasing storm size is to increase the subsequent

streamward head gradient and thus the pulse release of $\mathrm{NO}_{3}$, resulting in a net $\mathrm{NO}_{3}$ load that increases with Cobb Mill Creek, we can examine the effects of water 
magnitude of storms (Figure 7a). Conversely, for high diffusivity, the major influence induced by increased stream stage is the reduction of the streamward hydraulic storage by using mathematical modeling. Water stored in

the sediments as a result of passage of a flood wave resides there for different durations depending on the magnitude and duration of the event. During small events, the residence time of stored water is of the order of a few days, gradient, which allows much longer residence time of water in the subsurface where it undergoes denitrification. As a result, larger flood waves lead to more reduction of $\mathrm{NO}_{3}^{-}$and lower net loading to the stream (Figure 7b).

[34] Denitrification accounts for significant removal of reactive forms of $\mathrm{N}$ on the global scale [Galloway et al., 2004]. The large temporal variability of denitrification is one of the major impediments to a comprehensive under- 
standing of denitrification [Davidson and Seitzinger, 2006]. Most of the temporal variation in nitrate concentrations in surface streams is associated with floods [Matrti, 2000]. Butturini and Sabater [2002] found that storm discharge explained $47 \%$ of the annual $\mathrm{NO}_{3}-\mathrm{N}$ concentration variance in their study in a small perennial Mediterranean catchment in Spain.

\section{[35] Other transient effects might also affect $\mathrm{NO}_{3}{ }^{-}$load-}

ing, but this study demonstrates that they are not required. The scouring of algae and biomass attached to the sediment surface during storms may release algal exudates and other labile organic compounds that would support transient denitrification in the shallow sediments [Holmes et al., 1998], and extensive scouring of the bed in severe floods can obviously have a marked effect. The storm-induced change of nutrient spiraling, wherein nutrients are taken up and transported downstream in the biologically fixed form and then released back into the water with the death and decay of the organisms, can be another factor influencing $\mathrm{NO}_{3}^{-} \mathrm{N}$ export [Grimm and Fisher, 1984]. Also, seasonal changes in streamflow rates have been observed to alter denitrification in bed sediments [Ruehl et al., 2007]. Finally, transient effects due to hyporheic exchange have been mathematically modeled by Boano et al. [2007]. Although recognizing that multiple transient effects may play some

role in generating temporal variation of $\mathrm{NO}_{3}{ }^{-}$loading, the

present study offers a possible mechanism that independently accounts for transient export of reactive solutes. The passage of a freshet results in a pressure wave that pushes surface water into the subsurface as constrained by the sediment diffusivity and the peak stream stage. The head gradient set up by the freshet determines the groundwater flow velocity and therefore the residence time of the water in the streambed sediments. The balance between the rates of groundwater flow through organic-rich sediments and of denitrification ultimately determines the efflux of nitrate to the stream. The transient impact on nitrate loading suggested by results from the numerical model indicates that high flood stage and low-sediment hydraulic diffusivity can result in excess nitrate loading to surface water following storm events, whereas large sediment hydraulic diffusivity, regardless of the size of stream stage changes, facilitates greater removal of $\mathrm{NO}_{3}$ by denitrification by allowing for a longer residence time of water in the subsurface.

[36] Acknowledgments. This research was supported by funding from the National Science Foundation under grant NSF-EAR 0208386. We thank Holly S. Galavotti, Joseph M. Battistelli, and Samuel A. Flewelling for assistance with field and laboratory work. The Virginia Coast Reserve LTER provided accommodation and logistical support during the fieldwork. We thank three anonymous reviewers for constructive comments on a draft of this paper.

\section{References}

Arntzen, E. V., D. R. Geist, and P. E. Dresel (2006), Effects of fluctuating river flow on groundwater/surface water mixing in the hyporheic zone of a regulated, large cobble bed river, River Res. Appl., 22, 937 - 946, doi:10.1002/rra.947.

Barlow, P. M., L. A. DeSimone, and A. F. Moench (2000), Aquifer response to stream-stage and recharge variations: II. Convolution method and applications, J. Hydrol., 230, 211 - 229, doi:10.1016/S00221694(00)00176-1.

Boano, F., R. Revelli, and L. Ridolfi (2007), Bedform-induced hyporheic exchange with unsteady flows, Adv. Water Resour., 30, 148 - 156, doi:10.1016/j.advwatres.2006.03.004.
Bolster, C. H., A. L. Mills, G. M. Hornberger, and J. S. Herman (1999), Spatial distribution of deposited bacteria following miscible displacement experiments in intact cores, Water Resour. Res., 35, 1797 - 1807, doi:10.1029/1999WR900031.

Butturini, A., and F. Sabater (2002), Nitrogen concentrations in a small Mediterranean stream: 1. Nitrate, 2. Ammonium, Hydrol. Earth. Syst. Sci., 6, $539-550$.

Cey, E. E., D. L. Rudolph, R. Aravena, and G. Parkin (1999), Role of the riparian zone in controlling the distribution and fate of agricultural

nitrogen near a small stream in southern Ontario, J. Contam. Hydrol.,

37, 45 - 67, doi:10.1016/S0169-7722(98)00162-4.

Chen, X. H. (2007), Hydrologic connections of a stream-aquifer-vegetation zone in south-central Platte River valley, Nebraska, J. Hydrol., 333, 554 - 568, doi:10.1016/j.jhydrol.2006.09.020.

Chen, X., and X. H. Chen (2003), Stream water infiltration, bank storage, and storage zone changes due to stream-stage fluctuations, J. Hydrol., 280,246 - 264, doi:10.1016/S0022-1694(03)00232-4.

Chen, Y. M., L. M. Abriola, P. J. J. Alvarez, P. J. Anid, and T. M. Vogel (1992), Modeling transport and biodegradation of benzene and toluene in sandy aquifer material: Comparisons with experimental measurements, Water Resour. Res., 28, 1833 - 1847, doi:10.1029/92WR00667.

Cirmo, C. P., and J. J. McDonnell (1997), Linking the hydrologic and biogeochemical controls of nitrogen transport in the near-stream zones of temperate-forested catchments: A review, J. Hydrol., 199, 88 - 120, doi:10.1016/S0022-1694(96)03286-6.

Cooper, H. H., and M. Rorabaugh (1963), Groundwater movements and bank storage due to flood stages in surface stream, U.S. Geol. Surv. Water Supply Pap., 1536-J, 343 - 366.

Dahm, C. N., N. B. Grimm, P. Marmonier, H. M. Valett, and M. Vervier (1998), Nutrient dynamics at the interface between surface waters and groundwaters, Freshwater Biol., 40, 427 - 451, doi:10.1046/j.1365-

2427.1998.00367.x.

Davidson, E. A., and S. Seitzinger (2006), The enigma of progress in denitrification research, Ecol. Appl., 16, 2057 - 2063, doi:10.1890/ 1051-0761(2006)016[2057:TEOPID]2.0.CO;2.

Doussan, C., G. Poitevin, E. Ledoux, and M. Detay (1997), River bank filtration: Modelling of the changes in water chemistry with emphasis on nitrogen species, J. Contam. Hydrol., 25, 129 - 156, doi:10.1016/S01697722(96)00024-1.

Duff, J. H., and F. J. Triska (1990), Denitrification in sediments from the hyporheic zone adjacent to a small forested stream, Can. J. Fish. Aquat. Sci., 47,1140 - 1147.

Fischer, U. H., P. R. Porter, T. Schuler, A. J. Evans, and G. H. Gudmundsson (2001), Hydraulic and mechanical properties of glacial sediments beneath Unteraargletscher, Switzerland: Implications for glacier basal motion, Hydrol. Processes, 15, 3525 - 3540, doi:10.1002/hyp.349.

Galavotti, H. (2004), Spatial profiles of sediment denitrification at the ground water-surface water interface in Cobb Mill Creek on the Eastern Shore of Virginia, M.S. thesis, Univ. of Va., Charlottesville.

Galloway, J. N., et al. (2004), Nitrogen cycles: Past, present, and future, Biogeochemistry, 70, 153 - 226.

Grimm, N. B., and S. G. Fisher (1984), Exchange between interstitial and surface-water: Implications for stream metabolism and nutrient cycling, Hydrobiologia, 111,219 - 228, doi:10.1007/BF00007202.

$\mathrm{Gu}, \mathrm{C}$. (2007), Hydrological control on nitrate delivery through the groundwater surface water interface, Ph.D. thesis, 250 pp., Univ. of Va., Charlottesville.

Gu, C., G. M. Hornberger, A. L. Mills, J. S. Herman, and S. A. Flewelling (2007), Nitrate reduction in streambed sediments: Effects of flow and biogeochemical kinetics, Water Resour. Res., 43, W12413, doi:10.1029/ 2007 WR006027.

Hancock, P. J., and A. J. Boulton (2005), The effects of an environmental flow release on water quality in the hyporheic zone of the Hunter River, Australia, Hydrobiologia, 552, 75 - 85, doi:10.1007/s10750-005-1506-5.

Harvey, J. W., and K. E. Bencala (1993), The effect of streambed topography on surface-subsurface water exchange in mountain catchments, Water Resour. Res., 29, 89 - 98, doi:10.1029/92WR01960.

Hedin, L. O., J. C. von Fischer, N. E. Ostrom, B. P. Kennedy, M. G. Brown, and G. P. Robertson (1998), Thermodynamic constraints on nitrogen transformations and other biogeochemical processes at soil-stream interfaces, Ecology, 79, $684-703$.

Holmes, R. M., S. G. Fisher, N. B. Grimm, and B. J. Harper (1998), The impact of flash floods on microbial distribution and biogeochemistry in the parafluvial zone of a desert stream, Freshwater Biol., 40, 641 - 654. doi:10.1046/j.1365-2427.1998.00362.x. 
Kindred, J. S., and M. A. Celia (1989), Contaminant transport and biodegradation: 2. Conceptual-model and test simulations, Water Resour. Res., 25, 1149 - 1159, doi:10.1029/WR025i006p01149.

Kinzelbach, W., W. Schafer, and J. Herzer (1991), Numerical modeling of natural and enhanced denitrification processes in aquifers, Water Resour. Res., 27, 1123 - 1135, doi:10.1029/91WR00474.

MacQuarrie, K. T. B., E. A. Sudicky, and E. O. Frind (1990), Simulation of biodegradable organic contaminants in groundwater: 1. Numerical formulation in principal directions, Water Resour. Res., 26, 207 - 222.

MacQuarrie, K. T. B., E. A. Sudicky, and W. D. Robertson (2001), Numerical simulation of a fine-grained denitrification layer for removing septic system nitrate from shallow groundwater, J. Contam. Hydrol., 52, 29 - 55, doi:10.1016/S0169-7722(01)00152-8.

Martinec, J. (1985), Time in Hydrology, pp. 249 - 290, John Wiley, Hoboken, N. J.

Matrti, E. (2000), Flood Frequency and Stream-Riparian Linkages in Arid Lands, pp. 111 - 136, Academic, San Diego, Calif.

Mixon, R. B. (1985), Stratigraphic and geomorphic framework of uppermost Cenozoic deposits in the southern Delmarva Peninsula, Virginia and Maryland, U.S. Geol. Surv. Prof. Pap., 1067-C, 53 pp.

Ocampo, C. J., C. E. Oldham, and M. Sivapalan (2006), Nitrate attenuation in agricultural catchments: Shifting balances between transport and reaction, Water Resour. Res., 42, W01408, doi:10.1029/2004WR003773.

Pinay, G., C. Ruffinoni, S. Wondzell, and F. Gazelle (1998), Change in groundwater nitrate concentration in a large river floodplain: Denitrification, uptake, or mixing?, J. N. Am. Benthol. Soc., 17, 179 - 189, doi:10.2307/1467961.

Robertson, W. D., and J. A. Cherry (1995), In-situ denitrification of septicsystem nitrate using reactive porous-media barriers: Field trials, Ground Water, 33, 99 - 111, doi:10.1111/j.1745-6584.1995.tb00266.x.
Ruehl, C. R., C. E. Hatch, A. T. Fisher, M. Los Huertos, C. Shennan, S. D. Wankel, C. Kendall, and C. G. Wheat (2007), Nitrate dynamics within the Pajaro River, a nutrient-rich losing stream, J. N. Am. Benthol. Soc., 26, 191 - 206, doi:10.1899/0887-3593(2007)26[191:NDWTPR]2.0.CO;2.

Singh, K. P. (1968), Some factors affecting baseflow, Water Resour. Res., 4, 985 - 999, doi:10.1029/WR004i005p00985.

Squillace, P. J. (1996), Observed and simulated movement of bank-storage water, Ground Water, 34, 121 - 134, doi:10.1111/j.1745-6584.1996.tb01872.x.

Squillace, P. J., E. M. Thurman, and E. T. Furlong (1993), Groundwater as a nonpoint-source of atrazine and deethylatrazine in a river during baseflow conditions, Water Resour. Res., 29, 1719 - 1729, doi:10.1029/ 93WR00290.

Toride, N., F. J. Leij, and M. T. van Genuchten (1995), The CXTFIT code for estimating transport parameters from laboratory or field tracer experiments, Version 2.0, research report, U.S. Salinity Lab., USDA Agric. Res. Serv., Riverside, Calif.

Valett, H. M. (1993), Surface-hyporheic interactions in a Sonoran Desert stream: Hydrologic exchange and diel periodicity, Hydrobiologia, 259, 133 - 144, doi:10.1007/BF00006593.

Wang, K., and E. E. Davis (1996), Theory for the propagation of tidally induced pore pressure variations in layered subseafloor formations, $J$. Geophys. Res., 101(B5), 11,483 - 11,495, doi:10.1029/96JB00641.

C. Gu, Berkeley Water Center, University of California, Berkeley, Berkeley, CA 94729, USA. (cgu@berkeley.edu)

J. S. Herman, G. M. Hornberger, and A. L. Mills, Department of Environmental Sciences, University of Virginia, Charlottesville, VA 229044123,USA. (jherman@virginia.edu; gmh3k@virginia.edu; amills@virginia. edu) 